\title{
Discovery of a new species of Ozadelpha van Nieukerken sheds more light on the diagnostics of this controversial genus of Nepticulidae (Lepidoptera)
}

\author{
Jonas R. Stonis ${ }^{1,2 *}$, \\ Arūnas Diškus', \\ Andrius Remeikis², \\ Kenji Nishida ${ }^{3}$ \\ ${ }^{1}$ Vytautas Magnus University, \\ K. Donelaičio St. 58, \\ Kaunas 44248, Lithuania \\ ${ }^{2}$ Nature Research Centre \\ and Baltic-American \\ Biotaxonomy Institute, \\ Akademijos St. 2, \\ Vilnius 08412, Lithuania \\ ${ }^{3}$ Museo de Zoologia, \\ Universidad de Costa Rica \\ \& Estación Biológica Monteverde, \\ Apdo. 22-5655, Monteverde, \\ Costa Rica
}

\begin{abstract}
We describe a new species, Ozadelpha nigella Diškus \& Stonis, sp. nov., a leaf miner on Symplocos Jacq. (Ericales: Symplocaceae), from the Yungas biogeographical province, South America. We briefly discuss the issues of diagnostics of the recently erected genus Ozadelpha van Nieukerken. The genus is now comprised of four named species having shared characters useful for efficient identification and genus recognition. The new species is illustrated with photographs of the adults, male genitalia and leaf mines.
\end{abstract}

Keywords: leaf mines, Ozadelpha nigella, pygmy moths, Symplocos

\section{INTRODUCTION}

The family of Nepticulidae, or pygmy moths ("pygmies"), comprises the world's smallest moths the larvae of which are leaf miners during all stages of their development and make tunnels (leaf mines) in assimilatory tissues of wild or cultivated plants. The history of documentation of

* Corresponding author. Email: stonis.biotaxonomy@gmail.com the Nepticulidae fauna of the Neotropics counts about 133 years with the description of the first species from Colombia (see Puplesis, Robinson, 2000), but only during the recent decade it has become really active. A series of taxonomic publications on Nepticulidae covering Central and South America were published recently, notably, Remeikis et al., 2014; Stonis et al., 2013, 2014b, 2015, 2016a, 2016b, 2016c, 2016d, 2017a, 2017b, 2017c, 2018a, 2018b, 2018c, 2018d, 2019; Stonis, 
Remeikis, 2015; van Nieukerken et al., 2016a, 2016b; Stonis, Diškus, 2018, etc.

Here, we continue to document the Nepticulidae fauna of the Neotropics and describe one more species, Ozadelpha nigella Diškus \& Stonis, sp. nov., feeding on Symplocos Jacq. (Symplocaceae) from the Yungas biogeographical province, Bolivia. This particular species belongs to the genus some aspects of diagnostics of which appeared controversial previously.

\section{MATERIALS AND METHODS}

The description of the new species is based on the material deposited in the collection of the Zoological Museum, Natural History Museum of Denmark, Copenhagen (ZMUC). In addition, some material of non-type series of Stigmella ovata Puplesis \& Robinson was available from the collection of Biosystematics Research Group, Vilnius, Lithuania (BRG, recently transferred to ZMUC).

Collecting methods and protocols for species identification and description are outlined in Puplesis (1994); Johansson et al. (1990); Puplesis, Diškus (2003); and Stonis et al. (2014a). Permanent preparations on microscope slides were photographed and studied with a Leica DM2500 microscope and Leica DFC420 digital camera. Adults were photographed using a Leica S6D stereoscopic microscope with the attached Leica DFC290 digital camera. Molecular methods used in this paper are described in Stonis et al. (2019).

\section{DESCRIPTION OF OZADELPHA NIGELLA DIŠKUS \& STONIS, SP. NOV.}

Type material. Holotype: + , BOLIVIA, Nor Yungas Province, Coroico, $16^{\circ} 12^{\prime} 25^{\prime \prime} \mathrm{S}, 67^{\circ} 43^{\prime}$ $53^{\prime \prime} \mathrm{W}$, elevation $1660 \mathrm{~m}$, leaf-mining larvae on Symplocos sp., Symplocaceae 15.vi.2018, ex pupa vii.2018, field card no. 5265, leg. Diškus and Stonis, genitalia slide no. AD877ㅇ (ZMUC). Paratype: $1 \hat{\sigma}$, same label data as holotype, genitalia slide no. AD878 $\widehat{\jmath}$ (from the adult in pupal skin) (ZMUC).
Diagnosis. Ozadelpha nigella sp. nov. differs from all congeneric species in the silvery shiny spots on the forewing and dark silvery shiny forewing base and thorax. In the male genitalia, the new species differs in the unique-shaped valva (Figs. 23, 24), wide gnathos (Fig. 21), and the unique set of conuti of the phallus (Fig. 27). In the female genitalia, O. nigella sp. nov. differs in the combination of a small, folded corpus bursae, ductus spermathecae without distinctive coils, slender anterior apophyses, and very long posterior ones. The host plant, Symplocos, also makes this species distinctive because no other Ozadelpha species are known to feed on Symplocaceae.

Male. Known from an adult in pupal skin; externally resembles female; for external characters see the female description.

Female (Figs. 12-15). Forewing length about $1.7 \mathrm{~mm}$; wingspan about $4.4 \mathrm{~mm}$. Head: palpi and frons (face) yellow-silvery glossy; frontal tuft (Fig. 13) orange-ochre or orange-brown; collar blackish brown to dark orange-brown, comprised of very slender scales; scape yellowsilvery glossy; antenna shorter than one half the length of forewing; flagellum with about 21 segments, black with some purple iridescence on upper side, black-grey on underside. Thorax and tegula dark silvery shiny to silvery shiny depending on the angle of view. Forewing (Figs. 12, 15) dark silvery shiny basally, but brownish black to black with purple iridescence in apical $2 / 3$; spots only on apical part of forewing, very distinctive, comprised of uplifted, silvery shiny scales, some of them white-tipped (Fig. 14); fringe black, silvery shiny; fringe line absent; underside of forewing blackish brown, with purple and coppery gloss, without spots. Hindwing and fringe grey-black on the upper side and underside. Legs glossy, grey with purple iridescence, except yellow, silvery shiny femur of the foreleg, tibia of midleg, and tarsi of the hind leg. Abdomen grey-black with some purple iridescence on the upper side, whitish grey with metallic gloss on the underside; abdominal apex pointed distally, without tufts.

Male genitalia (Figs. 19-27). Capsule significantly longer $(330-355 \mu \mathrm{m})$ than wide 

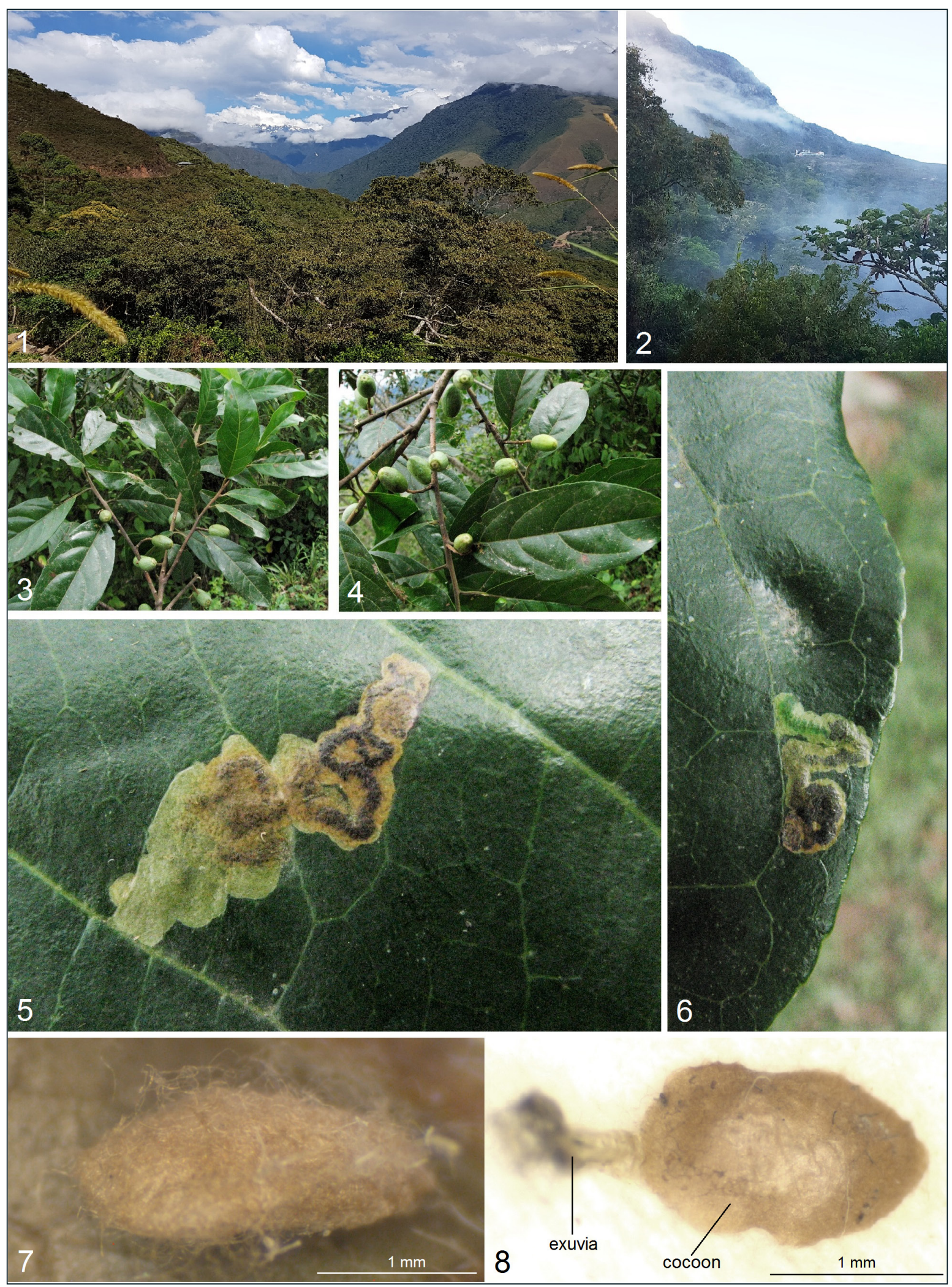

Figs. 1-8. Bionomics of Ozadelpha nigella Diškus \& Stonis, sp. nov.; 1,2 - type locality and habitat, the Yungas, Coroico, Bolivia, at an elevation of about $1660 \mathrm{~m} ; 3,4$ - host plant, Symplocos Jacq. (probably S. arechea L'Hér.), Symplocaceae (identified by Dr. Alfredo F. Fuentes, Universidad Mayor de San Andres, Bolivia); 5, 6 - leaf mines; 7,8 - cocoon 

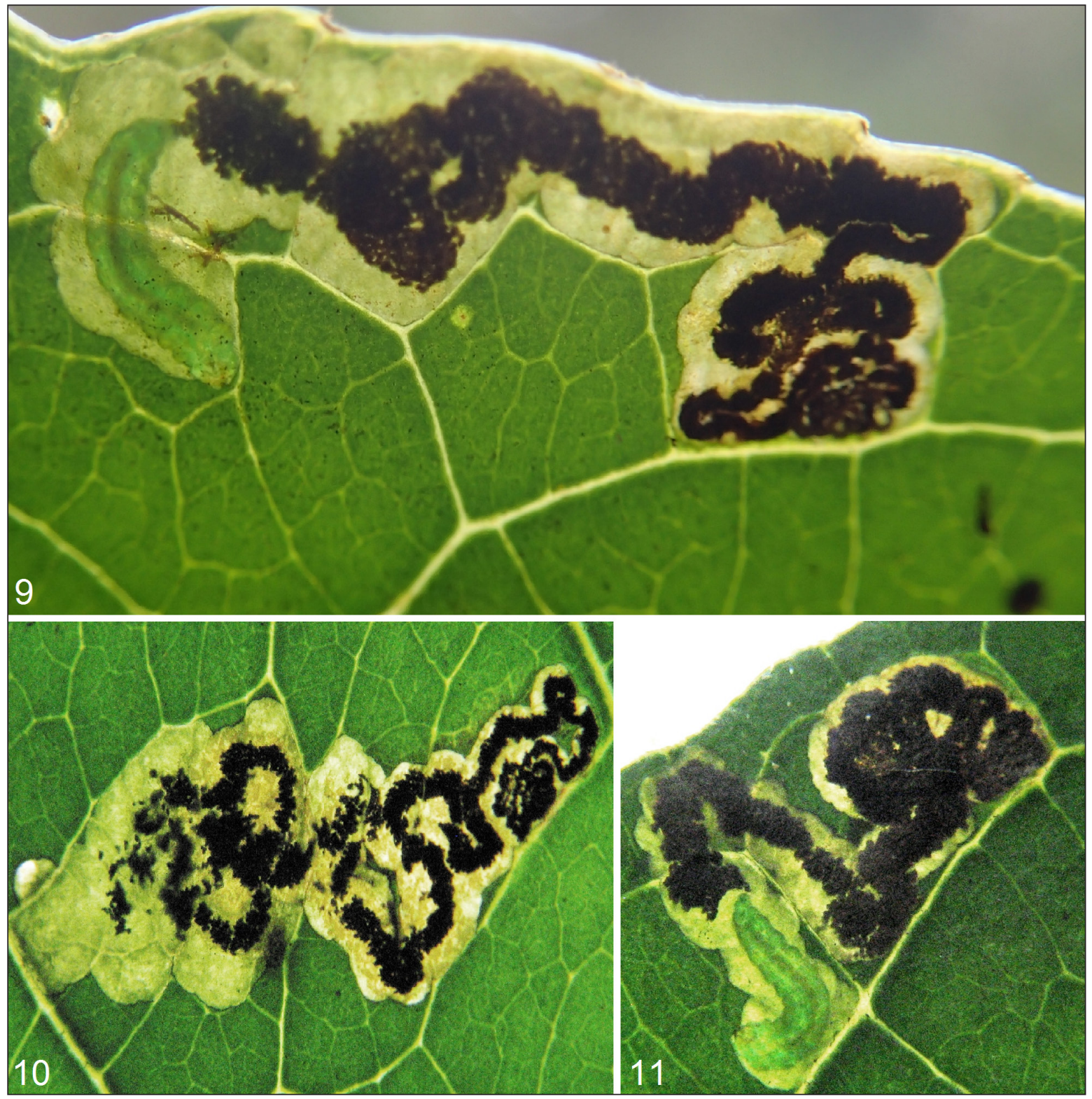

Figs. 9-11. Documentation of leaf mines and larva of Ozadelpha nigella Diškus \& Stonis, sp. nov. on Symplocos sp., Symplocaceae (note the contorted beginning of the gallery in all samples)

$(180 \mu \mathrm{m})$. Pseuduncus absent. Uncus (Fig. 19) wide, truncated distally. Gnathos (Figs. 21, 26) with wide, rounded central element and slender arms. Valva (Figs. 23, 24, 26) $140 \mu \mathrm{m}$ long, 60$65 \mu \mathrm{m}$ wide, with an inner lobe basally (Fig. 23) and slender apical process (Fig. 24); transtilla with an elaborated transverse bar (Fig. 22), without sublateral processes. Juxta (Fig. 24) small, sometimes inconspicuous. Vinculum very large, without lateral lobes, widely rounded (Figs. 22, 23). Phallus (Fig. 27) $305 \mu \mathrm{m}$ long, $60 \mu \mathrm{m}$ wide, but widened basally (90 $\mu \mathrm{m}$ wide); vesica with a distinctive cathrema (Fig. 27) and unique set of mostly triangular, plate-like cornuti.

Female genitalia (Figs. 16-18). Total length about $320 \mu \mathrm{m}$. Corpus bursae small and heavily folded. Ductus spermathecae with indistinctive coils.

Bionomics (Figs. 1-11). Host plant is Symplocos Jacq. (Figs. 3, 4), probably S. arechea L'Hér., Symplocaceae (identified on the basis of photographs by Dr. Alfredo F. Fuentes, 


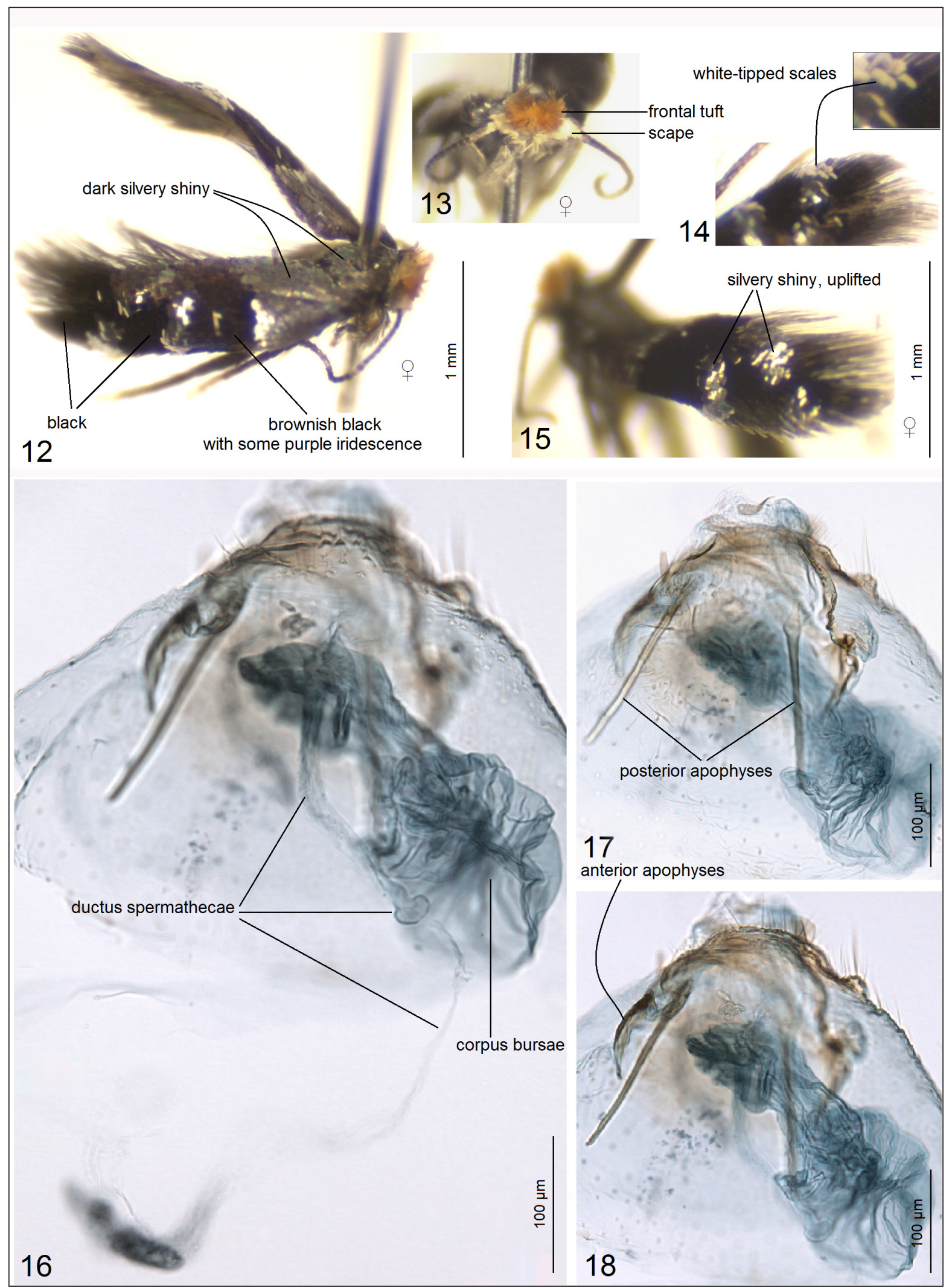

Figs. 12-18. Female of Ozadelpha nigella Diškus \& Stonis, sp. nov., holotype; 12-15 - adult; 16-18 - female genitalia, overview at different focal length, slide no. AD877 (ZMUC) 


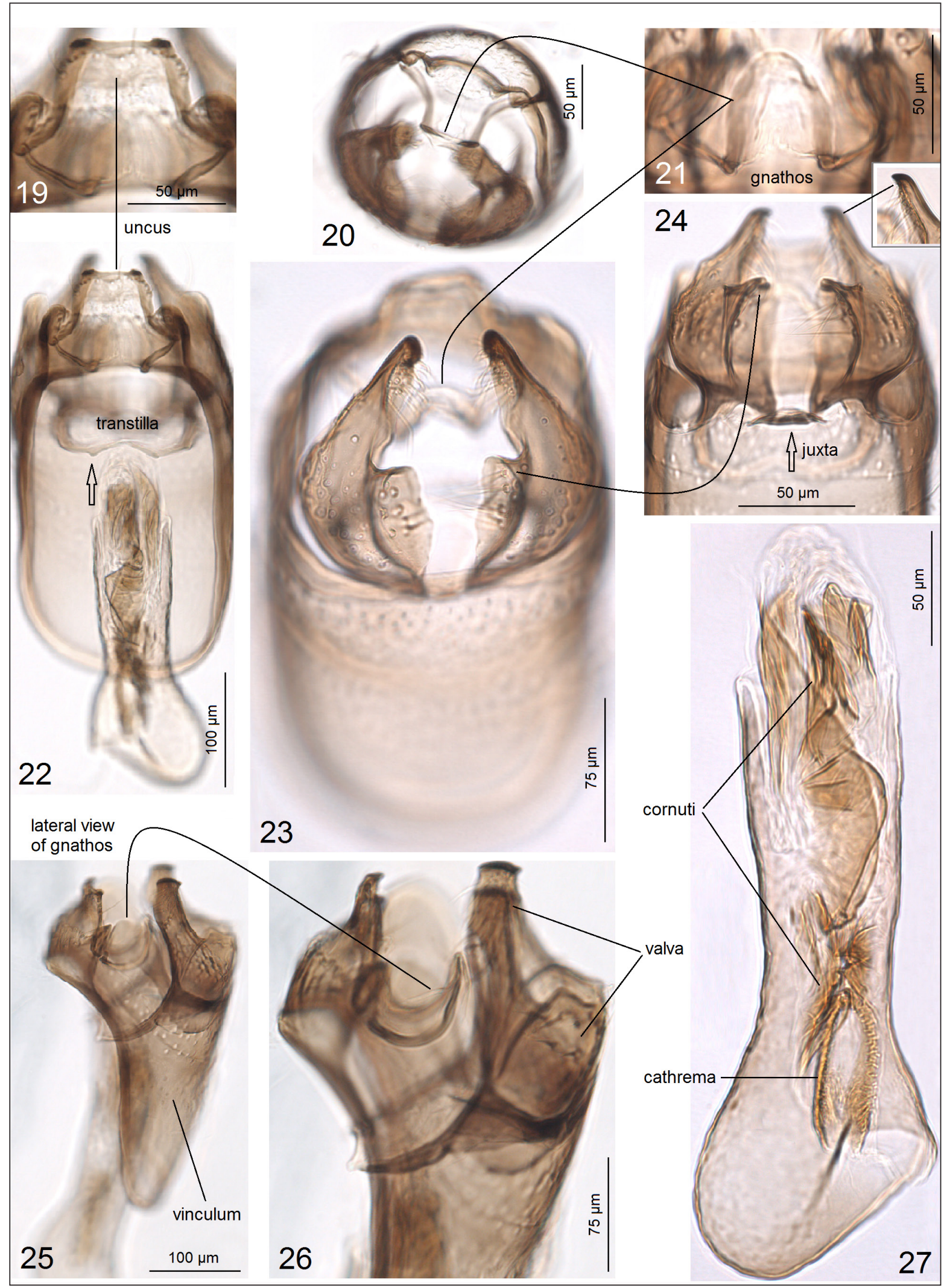

Figs. 19-27. Male genitalia of Ozadelpha nigella Diškus \& Stonis, sp. nov., paratype, slide no. AD878 (ZMUC); 19-26 - genitalia capsule at a different angle of view (22, 25 - with phallus); 27 - phallus 
Universidad Mayor de San Andres, Bolivia). Egg laid singly on the underside of the leaf; egg case very small, oval-shaped, silvery glossy, black when filled with frass. Larvae mine leaves in June; voltinism unknown. Larva (Figs. 9, 11) bright green with a slender, pale brown intestine and pale brown head. Leaf mine (Figs. 5, 6, 9-11) starts as a slender but contorted gallery filled with black frass; further on, the gallery gradually widens, with a wide central line of black frass (Figs. 9-11). Pupation outside the leaf mine, possibly in debris or litter because no cocoons were observed on the host plants. Exit slit on the upper side of the leaf. Cocoon (Figs. 7,8 ) beige, without a distinct flat rim around the main body. Adults emerged in late July. Otherwise, biology is unknown.

DNA barcode. We barcoded the holotype of the new species; the sequence is available at GenBank under voucher/sample ID MN813061.

Distribution. Currently known from a single locality in Bolivia (Nor Yungas: Coroico), at an elevation of about $1660 \mathrm{~m}$ (Figs. 1, 2).

Etymology. The species name derived from the Latin nigellus (blackish, dark), in reference to the brownish black forewing of the new species (not after Nigel P. Farage, U.K.).

\section{RE-DEPOSITION OF THE TYPE SERIES OF OZADELPHA GUAJAVAE PUPLESIS \& DIŠKUS, 2002}

During the preparation of the current paper, the entire series of the type material of Ozadelpha guajavae Puplesis \& Diškus, described in Puplesis et al., 2002 was transferred to ZMUC.

Type material: $1 \hat{\delta}$ (holotype), Ecuador, $80 \mathrm{~km}$ E Guayaquil, Bucay, western foothills of Andes, $700 \mathrm{~m}$, premontane tropical forest and orchards, 16-19.i.2001, leg. Puplesis and Hill, genitalia slide no. AD0340; 5 $\lambda, 2$ q (paratypes), same label as holotype, slide nos. $\mathrm{AD} 0341 \hat{\sigma}, \mathrm{AD} 0342 \hat{\jmath}, \mathrm{AD} 0343$ +, $\mathrm{AD} 0344$ 우, AD0346 (forewing venation), RA1035 (forewing venation).

Remarks. The following additional material $(2 \hat{O}, 1$, non-type series, collected in Ec- uador, Loja province, Vilcabamba, $4^{\circ} 15^{\prime} 44^{\prime \prime}$, $79^{\circ} 13^{\prime} 53^{\prime \prime} \mathrm{W}$, elevation ca. $1800 \mathrm{~m}$, on Psidium guajava, 16-18.ii.2014, leg. Remeikis and Stonis, genitalia slide nos. RA611 ${ }^{\lambda}$, RA 612 9 ) was deposited at ZMUC earlier.

\section{DISCUSSION}

The controversy of Ozadelpha. The genus is among the most recently described genera of Nepticulidae (van Nieukerken et al., 2016b). The primary description was based on three named species: Ozadelpha conostegiae van Nieukerken \& Nishida (the type species from Costa Rica), the Argentinian O. ovata (Puplesis \& Robinson), published in Puplesis, Robinson, 2000, and the Ecuadorian O. guajavae (Puplesis \& Diškus, 2002) published in Puplesis et al., 2002. Now, with the description of the Bolivian O. nigella sp. nov., this small genus contains four named species and one unnamed species, "specimen EvN4680", which was documented on a female only (van Nieukerken et al., 2016b). It is interesting that, at first look, some species of Ozadelpha possess characters somehow resembling those in other genera. For example, the rounded thickening in the female genitalia of $O$. conostegiae resembles that in the Australian Pectinivalva brevipalpa Hoare, and the blunt anterior apophyses are similar to the apophyses of some Australian and South American Simplimorpha (sensu lato). The large rounded vinculum and basally widened valva of all Ozadelpha resemble the analogous structures in Simplimorpha. In the female genitalia, the short corpus bursae of $O$. guajavae and $O$. nigella also have some similarity with the corpus bursae of Simplimorpha. On the other hand, the Ozadelpha species vary significantly from species to species. It made the genus and its diagnostics controversial, and previously we, the first three authors, had not been sure about the monophyly of the taxon. In the process of the current study, we observed several issues that need to be discussed.

Collar in Ozadelpha. It was stated in the original differential diagnosis of the genus (van Nieukerken et al., 2016b) that the genus was recognised by the collar with lamellar scales. We 
found that only O. conostegiae possessed a collar of lamellar scales. The collar of O. ovata is comprised of distinctly piliform scales, and the collar of O. guajavae, and especially of $O$. nigella, represents an intermediate state: in O. guajavae, lamellar scales are long and slender and, at first look, resemble a collar of piliform scales; in O. nigella, lamellar scales are short and very slender and also resemble a collar of piliform scales.

Forewing venation in Ozadelpha (Figs. 2831). Contrary to the diagnosis provided in the primary description, we believe that O. conostegiae possesses a closed cell (Fig. 28) formed by a cross vein, which was expected to be a staining artefact (van Nieukerken et al., 2016b). During the current study we also reexamined the forewing venation of $O$. guajavae and confirmed that the absence of $\mathrm{CuA}$ in O. guajavae in the earlier published study (Puplesis et al., 2002: Fig. 2) is not entirely an artefact, but represents a case of strong vein reduction (Figs. 30, 31). Thus it also confirms that the forewing venation in the genus differs from species to species (Figs. 28-31). Since the wing venation is strongly reduced in the Nepticulidae in general, the observed variation of venation in Ozadelpha makes this character less convenient for the genus recognition.

Host-plant relationships. By describing O. nigella, we introduce a new host plant genus (Symplocos) and a new host-plant family (Symplocaceae), both previously unknown for Nepticulidae. This is also important for another reason: earlier it was believed that Ozadelpha species were feeders on Myrtales (rosids), while in the case of O. nigella, the discovered host plant belongs to Ericales (asterids!). It certainly added more controversy to the understanding and diagnostics of Ozadelpha.

Diagnostics of the genus. We found that despite the differences in the collar, wing venation, and host-plant preferences, there were some shared external or internal characters of the Ozadelpha species (Fig. 32) making the genus recognition rather easy. We do not know which of these characters may represent synapomorphies and which, plesiomorphies. In addition to the characters presented in our pictorial tool (Fig. 32), the following features were also useful in diagnostics of the genus: in the male genitalia, the phallus with rather wide, triangularly shaped, plate-like cornuti (except for O. ovata, which possesses triangular but slender cornuti) and in the female genitalia, corpus bursae small, except for O. conostegiae.

Ozadelpha differs from the Gondwanan Simplimorpha (sensu lato) in the fully developed uncus and gnathos; these structures are reduced (absent) in Simplimorpha (for other apomorphies of Simplimorpha sensu lato, see Stonis et al., 2018d). From the Australian Pectinivalva, the Ozadelpha genus differs in many characters, including the gnathos in a shape of inverted $\mathrm{V}$, very long and rounded vinculum, different shape of valva, presence of transtilla, etc.

Phylogenetical position of Ozadelpha. In earlier molecular studies (Doorenweerd et al., 2016), Ozadelpha was always grouped together with the Australian Roscidotoga (van Nieukerken et al., 2016b); Roscidotoga was recently recognized as a subgenus of the Gondwanan Simplimorpha (Stonis et al., 2018d) and it also feeds on Myrtaceae in Australia and South America.

We barcoded $O$. nigella (the sequence is available at GenBank under voucher/sample ID MN813061) and O. guajavae (the sequence is available at at the BOLD database under voucher/sample ID ADH4024). Some barcodes of O. conostegiae, O. specimen EvN46680, O. ovata, and of some species of Simplimorpha and Pectinivalva are available at GenBank thanks to the earlier research by our colleagues Erik van Nieukerken, Camiel Doorenweerd, and Robert Hoare.

Because of fragmented and short sequences, we had experienced difficulties in putting $O$. nigella with $O$. ovata together on the same tree (O. ovata was often erroneously appearing at the very base of the branching, separately from the remaining Ozadelpha). Therefore, for Figs. 33 and 34, we used only O. guajavae and $O$. conostegiae. Once again, it was interesting to find how molecular phylogenies could be contradictive and even useless because of different sets of available barcodes or the length of sequences, etc. Within Ozadelpha, the species also 


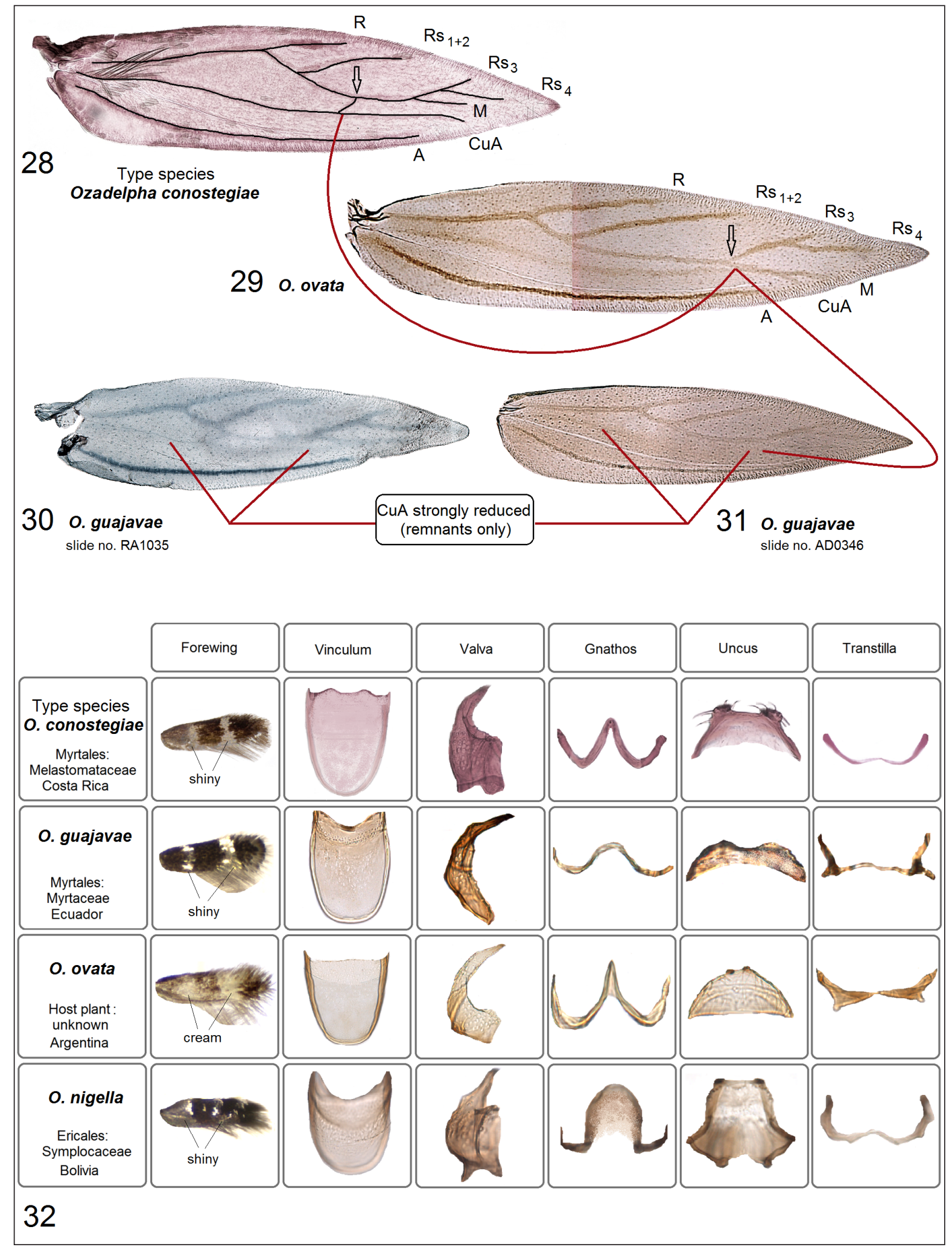

Figs. 28-32. Diagnostics of Ozadelpha; 28 - forewing venation, O. conostegiae van Nieukerken \& Nishida (after van Nieukerken et al., 2016b); 29 - same, O. ovata (Puplesis \& Robinson, 2000); 30, 31 - same, O. guajavae (Puplesis \& Diškus, 2002); 32 - diagnostics of Ozadelpha spp. showing the shared characters 
clustered in at least two different ways. In our best-resolved tree (Fig. 35), the Ericales feeder (O. nigella) turned out to be a sister group to the Myrtales feeders (O. conostegiae, O. specimen EvN4680, and O. guajavae). Our alternative tree is different (Fig. 36): in this case, O. guajavae and $O$. nigella clustered together, as a sister group to O. conostegiae + O. specimen EvN4680; it finds support in the male and female morphology, but little support in the host-plant relationships.

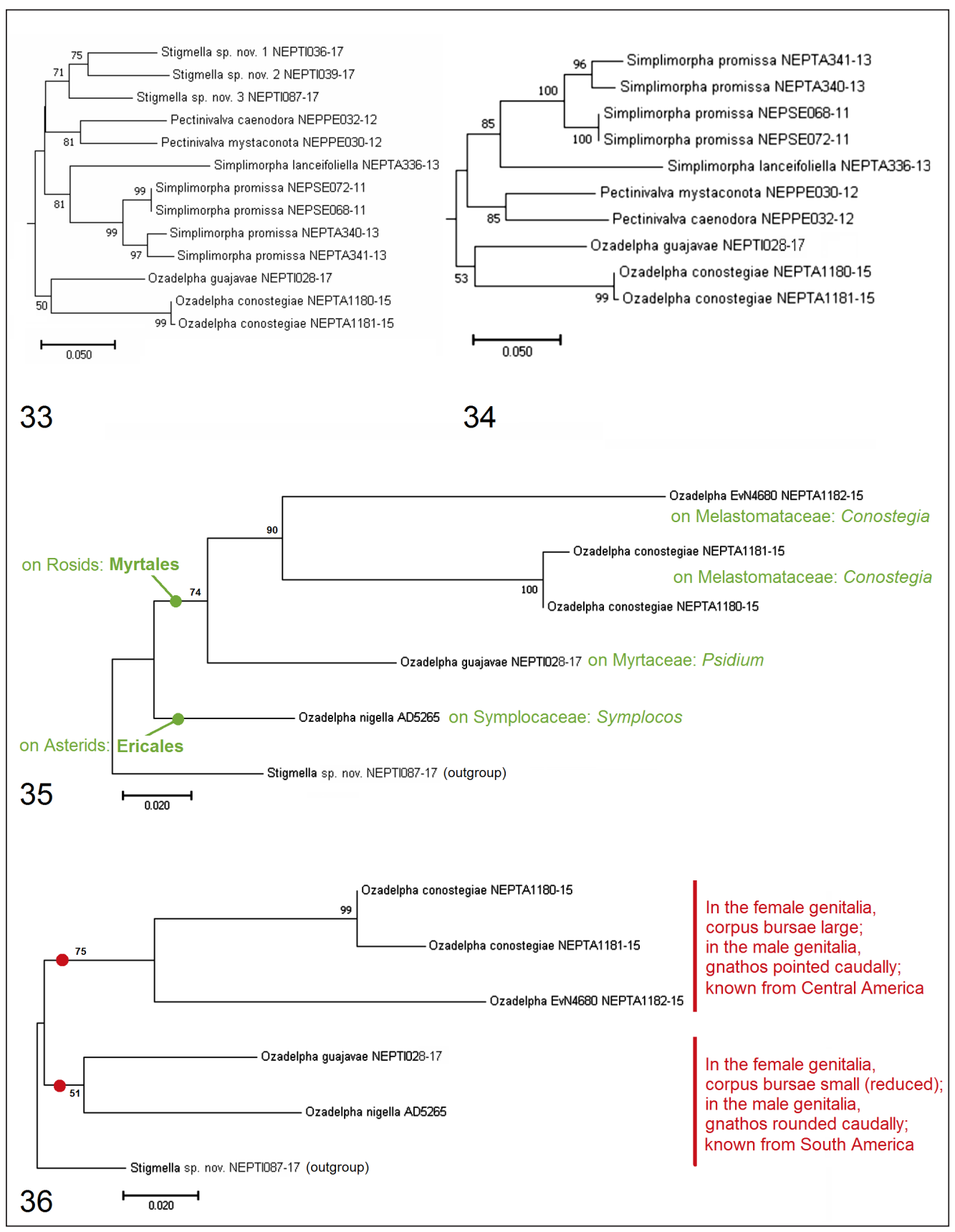

Figs. 33-36. Major versions of the Neighbour-Joining tree of Ozadelpha; 33, 34 - fragments, both showing Ozadelpha as a basal clade (the Neotropical Pseudopostega sp., Opostegidae were used an outgroup for full tree); 35, 36 - possible relationships of Ozadelpha spp. The divergence was calculated using the Kimura 2-parameter model based on 657 (for Figs. 33-35) and 219 bp mtDNA COI sequences (for Fig. 36). Bootstrap values lower than 50 are not shown 


\section{CONCLUSIONS}

Drawing upon the shared characters, we conclude that diagnostics of Ozadelpha is possible and the genus most likely represents a separate and probably a monophyletic entity; molecular data do not contradict it. However, the exact phylogenetic position of Ozadelpha remains unclear.

\section{ACKNOWLEDGEMENTS}

We are indebted to our Ecuadorian scientific partners, including those who participated in the initial project in 1999 by R. Puplesis and S. R. Hill, with Professor Giovanni Onore, a former professor at the Pontifical Catholic University of Ecuador, Quito, Ecuador. J. R. Stonis thanks the Environmental Programme at the Andes Office of NGO DAR Peru for permission to provide training courses and fieldwork within the framework of the project "Rapid assessment of biodiversity plots of critical value in the provinces Chanchamayo and Satipo, Peru, and Bolivia", in cooperation with the Baltic-American Biotaxonomy Institute in 2017-2018.

The identification of Symplocos, a hostplant genus of Ozadelpha nigella by $\mathrm{Dr}$ Alfredo F. Fuentes (Universidad Mayor de San Andres, La Paz, Bolivia) was greatly appreciated. We are also grateful to the botanists who confirmed the identification: Dr José Luis Fernández-Alonso (Real Jardín Botanico, Madrid, Spain), Dr Arvind Singh (Banaras Hindu University, Varanasi, India), and Rajeev $\mathrm{Ku}-$ mar Singh (Botanical Survey of India, Kolkata, India).

This research was partially funded by a grant (S-MIP-19-30, "DiagnoStics") from the Research Council of Lithuania. Andrius Remeikis is grateful to the Research Council of Lithuania for the research stipend he was awarded in 2019.

Received 28 October 2019 Accepted 4 November 2019

\section{References}

1. Doorenweerd C, van Nieukerken EJ, Hoare RJB. Phylogeny, classification and divergence times of pygmy leaf-mining moths (Lepidoptera: Nepticulidae): the earliest lepidopteran radiation on Angiosperms? Syst Entomol. 2016; 42(1): 267-87. https://doi.org/10.1111/ syen. 12212

2. Johansson R, Nielsen ES, Nieukerken van EJ, Gustafsson B. The Nepticulidae and Opostegidae (Lepidoptera) of North West Europe. Fauna Entomol Scand. 1990; 23(1/2): 1-739.

3. Nieukerken van EJ, Doorenweerd C, Hoare JR, Davis DR. Revised classification and catalogue of global Nepticulidae and Opostegidae (Lepidoptera, Nepticuloidea). ZooKeys. 2016a; 628: 65-246. https://doi.org/10.3897/zookeys.628.9799

4. Nieukerken van EJ, Doorenweerd C, Nishida K, Snyers C. New taxa, including three new genera show uniqueness of Neotropical Nepticulidae (Lepidoptera). ZooKeys. 2016b; 628: 1-63. https://doi.org/10.3897/zookeys.628.9805

5. Puplesis R. The Nepticulidae of Eastern Europe and Asia: western, central and eastern parts. Leiden: Backhuys Publishers; 1994. 552 p.

6. Puplesis R, Diškus A. The Nepticuloidea \& Tischerioidea (Lepidoptera) - a global review, with strategic regional revisions. Kaunas: Lututè Publishers; 2003. 512 p.

7. Puplesis R, Robinson GS. A review of the Central and South American Nepticulidae (Lepidoptera) with special reference to Belize. Bull Nat Hist Mus Entomol. 2000; 69(1): 3-114. http://www.biodiversitylibrary.org/part/76459

8. Puplesis R, Diškus A, Robinson GS. New Neotropical Nepticulidae (Lepidoptera) from the western Amazonian rainforest and the Andes of Ecuador. Bull Nat Hist Mus Entomol. 2002; 71(1): 19-58. https://doi.org/10.1017/ s0968045402000020

9. Remeikis A, Stonis JR, Diškus A, Davis DR. The first photographic documentation and 
new data on Enteucha guajavae (Lepidoptera, Nepticulidae), a pest of guava from equatorial America. In: Stonis JR, Hill SR, Diškus A, Auškalnis T, editors. Selected abstracts and papers of the First Baltic International Conference on Field Entomology and Faunistics. Vilnius: Edukologija Publishers; 2014. p. 65-74.

10. Stonis JR, Diškus A. Acalyptris amazonensis sp. nov.: documentation of another leafmining species supplementing the unique but disputable A. latipennata group (Lepidoptera: Nepticulidae). Biologija. 2018; 64(3): 191-202. https://doi.org/10.6001/biologija.v64i3.3824

11. Stonis JR, Diškus A, Katinas L, Solis MA. Asteraceae: host to the greatest diversity of leafmining Nepticulidae (Lepidoptera) in South America? Proc Entomol Soc Wash. 2018a; 120(4): 856-902. https://doi. org/10.4289/0013-8797.120.4.856

12. Stonis JR, Diškus A, Remeikis A. The first description of the leaf-mining Nepticulidae (Lepidoptera) feeding on the South American plant genus Liabum, Asteraceae. Zootaxa. 2015; 4040(5): 576-82. http://dx.doi. org/10.11646/zootaxa.4040.5.6

13. Stonis JR, Diškus A, Solis MA. Two new Fabaceae-feeding Nepticulidae (Lepidoptera) from the Western Hemisphere, including a potential pest of the economically important Centrolobium Mart. ex Benth. Proc Entomol Soc Wash. 2018b; 120(4): 842-855. https://doi. org/10.4289/0013-8797.120.4.842

14. Stonis JR, Diškus A, Remeikis A, Cumbicus Torres N. Rosaceae-feeding Nepticulidae (Lepidoptera) of South America: some taxonomic and trophic diversity revealed. Biologija. 2016a; 62(4): 215-32. https://doi. org/10.6001/biologija.v62i4.3412

15. Stonis JR, Diškus A, Remeikis A, Davis DR, Solis MA, Cumbicus Torres N. The first record of Baccharis L. (Asteraceae) as a host-plant genus for Nepticulidae (Lepidoptera), with description of new Stigmella species from South America. Zootaxa. 2016b; 4136(1): 101-28. http://doi.org/10.11646/zootaxa.4136.1.4
16. Stonis JR, Diškus A, Remeikis A, Gerulaitis V, Karsholt O. Leaf-mining Nepticulidae (Lepidoptera) from record high altitudes: documenting an entire new fauna in the Andean páramo and puna. Monograph. Zootaxa. 2016c; 4181(1): 1-94. http://doi.org/10.11646/ zootaxa.4181.1.1

17. Stonis JR, Diškus A, Remeikis A, Karsholt O, Cumbicus Torres $\mathrm{N}$. Illustrated review of the leaf-mining Nepticulidae of the central Andes (Peru and Bolivia). Monograph. Zootaxa. 2017a; 4257(1): 1-70. http://doi.org/10.11646/ zootaxa.4181.1.1

18. Stonis JR, Diškus A, Remeikis A, Monro A. The mystery of the tiny Urticaceae-feeders: documentation of the first leaf-mining Nepticulidae (Lepidoptera) species from equatorial America associated with Phenax, Boehmeria and Pilea. Biologija. 2017a; 63(2): 105-25. https://doi.org/10.6001/biologija. v63i2.3523

19. Stonis JR, Diškus A, Remeikis A, Navickaitè A. Study methods of Nepticulidae: micro-mounts of genitalia structures. In: Stonis JR, Hill SR, Diškus A, Auškalnis T, editors. Selected abstracts and papers of the First Baltic International Conference on Field Entomology and Faunistics. Vilnius: Edukologija Publishers. 2014a; p. 32-5.

20. Stonis JR, Diškus A, Remeikis A, Noreika R, Schuster J. Four new leaf-mining Acalyptris species from Guatemala and Belize, with new data on bionomics of Stigmella pruinosa (Lepidoptera: Nepticulidae). Zootaxa. 2013; 3737(2): 101-17. http://dx.doi.org/10.11646/ zootaxa.3737.2.1

21. Stonis JR, Diškus A, Remeikis A, Karsholt O. Do leaf-mining Nepticulidae occur in the natural but so threatened Andean Polylepis forests? Biologija. 2016d; 62(2): 83-97. https:// doi.org/10.6001/biologija.v62i2.3334

22. Stonis JR, Diškus A, Remeikis A, Solis MA. The American Brachinepticula gen. nov. and Manoneura Davis (Nepticulidae): a new generic concept based on a reinforced cathrema 
in the phallus. Biologija. 2018c; 64(2): 99-128. https://doi.org/10.6001/biologija.v64i2.3735

23. Stonis JR, Diškus A, Remeikis A, Solis MA. A Gondwanan concept of Simplimorpha Scoble (sensu lato): a step toward clarity in the generic diagnostics of global Nepticulidae (Lepidoptera). Zootaxa. 2018d; 4521(2): 151-182. http://dx.doi.org/10.11646/zootaxa.4521.2.1

24. Stonis JR, Remeikis A, Davis DR. Ten new species from the Patagonian Andes (Argentina and Chile), mostly belonging to a newly designated Stigmella purpurimaculae group (Lepidoptera: Nepticulidae). Zootaxa. 2014b; 3887(3): 321-53.

25. Stonis JR, Remeikis A. The first records on the genus Acalyptris from the Caribbean (Lepidoptera: Nepticulidae). Zootaxa. 2015; 4057(1): 79-90. http://dx.doi.org/10.11646/ zootaxa.4057.1.4

26. Stonis JR, Remeikis A, Diškus A, Orlovskytè S., Vargas SA, Solis MA. A new leafmining pest of guava: Hesperolyra guajavifoliae sp. n., with comments on the diagnostics of the endemic Neotropical genus Hesperolyra van Nieukerken (Lepidoptera, Nepticulidae). ZooKeys (in press).

27. Stonis JR, Remeikis A, Diškus A, Forero D, Cumbicus Torres N. A report on Lamiaceaefeeding Nepticulidae (Lepidoptera) from South America. Zootaxa. 2017b; 4338(1): 128-140. https://doi.org/10.11646/zootaxa.4338.1.6

28. Stonis JR, Remeikis A, Diškus A, Megoran N. New species of leaf-mining Nepticulidae (Lepidoptera) from the Neotropical and AndoPatagonian regions, with new data on hostplants. Zootaxa. 2017c; 4272(1): 1-39. https:// doi.org/10.11646/zootaxa.4272.1.1
Jonas Rimantas Stonis, Arūnas Diškus, Andrius Remeikis, Kenji Nishida

\section{NAUJA MOKSLUI MAŽŲJŲ GAUBTAGALVIŲ (LEPIDOPTERA) RŪŠIS, PRIKLAUSANTI OZADELPHA VAN NIEUKERKEN GENČIAI}

\section{Santrauka}

Straipsnyje aprašoma nauja mokslui Ozadelpha nigella rūšis, aptikta Jungo miškų provincijoje, Bolivijoje (Pietų Amerika). Jos duomenys papildo šios kontroversiškos genties diagnostiką. Straipsnyje pateikiama išsami $O$. nigella suaugèlių, patino ir patelių genitalijų bei minų morfologijos dokumentacija. Aptariami Ozadelpha genties diagnostikos klausimai, išskiriami požymiai, leidžiantys identifikuoti taksoną.

Raktažodžiai: lapų minos, mažieji gaubtagalviai, Ozadelpha nigella, Symplocos 